Canadian University Music Review

Canadian University Music Review

Revue de musique des universités canadiennes

\title{
An Analysis of Schubert's "Der Neugierige": A Tribute to Greta Kraus
}

\section{David Beach}

Volume 19, numéro 1, 1998

URI : https://id.erudit.org/iderudit/1014606ar

DOI : https://doi.org/10.7202/1014606ar

Aller au sommaire du numéro

\section{Éditeur(s)}

Canadian University Music Society / Société de musique des universités canadiennes

ISSN

0710-0353 (imprimé)

2291-2436 (numérique)

Découvrir la revue

Citer cet article

Beach, D. (1998). An Analysis of Schubert's "Der Neugierige": A Tribute to Greta Kraus. Canadian University Music Review / Revue de musique des universités canadiennes, 19(1), 69-80. https://doi.org/10.7202/1014606ar
Résumé de l'article

This brief study is a tribute to Greta Kraus who taught for many years in the Faculty of Music, University of Toronto. It is a personal interpretation of a single song, "Der Neugierige" from Franz Schubert's Die schöne Müllerin, following the linear approach developed by Heinrich Schenker, with whom Greta studied many years ago in Vienna. Greta had maintained her interest in Schenker's ideas, particularly their practical application to performance issues, throughout her long and industrious teaching career.
All Rights Reserved ( C Canadian University Music Society / Société de musique des universités canadiennes, 1998
Ce document est protégé par la loi sur le droit d'auteur. L’utilisation des services d'Érudit (y compris la reproduction) est assujettie à sa politique d'utilisation que vous pouvez consulter en ligne.

https://apropos.erudit.org/fr/usagers/politique-dutilisation/ 


\section{AN ANALYSIS OF SCHUBERT'S 'DER NEUGIERIGE": A TRIBUTE TO GRETA KRAUS}

\section{David Beach}

At 3:00 p.m. on 8 May 1998, a congregation of approximately three hundred individuals assembled in Walter Hall at the Faculty of Music, University of Toronto, to pay tribute to one of Canada's preeminent musicians and teachers, the harpsichordist and pianist Greta Kraus (b. Vienna, 3 August 1907; d. Toronto, 30 March 1998). It was a wonderful event, both sad but at the same time exhilarating as a celebration of her rich life. There were tapes of Greta playing and speaking, tributes by former students and colleagues, and live performances by some of those whom she had coached. The outpouring of love and respect for this special person was enormous, one of those extraordinary events those of us fortunate enough to attend will remember for a long time.

As a relative newcomer to Toronto, I am fortunate to have had an opportunity to meet and talk with Greta Kraus. Our one meeting, which lasted about forty-five minutes, took place at her home several months before her death. She wanted to know all about my background and about my plans for the Faculty of Music, where she had been a long-time member of the faculty. But most of our time was spent talking about a common interest, the musical heritage of the famous Austrian musician-theorist, Heinrich Schenker (1868-1935). Greta had studied with Schenker in Vienna, and it is my understanding that after leaving Austria she had an invitation from Hans Weisse, another of Schenker's students, to teach at the Mannes College of Music in New York City. It is most fortunate for Canada and those who have studied with her that she had trouble with U.S. Immigration and instead settled here. Greta was well versed in Schenker's theoretical approach, as one can see in her graphic analysis of Chopin's Etude in F Major, op. 10, no. 8. ${ }^{1}$ But as a teacher I think she was not particularly interested in the theory but rather in the music principles upon which it is based: notions of line, direction, and closure.

Back to Walter Hall and the memorial tribute to Greta. At several points in the program, but particularly during a tape of her speaking about Schenker, my mind was drawn back to our one conversation. Then, near the close of the program, came a breathtaking performance of one of my favorite Schubert songs, "Der Neugierige," the sixth number from Die schöne Müllerin, by Russell Braun and Carolyn Maule. (I believe Russell said this was the first song

1 This analysis was published under Schenker's name as the fourth of Five Analyses in Sketchform (Fünf Urlinietafeln) (New York: David Mannes Music School, 1932). 
they had coached with Greta.) I was inspired by the performance and on the spot an idea occurred to me of how I might pay tribute to this wonderful individual who had shared her knowledge with so many of Canada's musicians: an analysis (including a Schenkerian graph) of this Schubert song. ${ }^{2}$ That is what leads me to this point. Though I barely had a chance to make her acquaintance, I suspect she would have enjoyed reading what follows-though not as much as hearing Russell and Carolyn performing the song!

The following is a rather literal translation of Müller's poem (see the reproduction of the score at the end of this article for the original German poem):

I ask no flowers,

I ask no stars;

they cannot all tell me

what I so dearly want to learn.

I am no gardener

the stars are too distant;

I will ask my brook

if my heart has lied to me.

O Brook of my love, how silent you are today!

I ask only one thing,

a single word one way or the other.

"Yes" is one word, the other is "no";

These two words encompass

for me the entire universe.

$O$ brook of my love

how peculiar you are today!

I will not repeat it,

tell me, brook, does she love me?

2 This brief study is intentionally limited to a close examination of a single song. Those interested in a detailed examination of the entire cycle, the poetry, and the music, should consult the following sources: Susan Youens, Schubert: "Die schöne Müllerin" (Cambridge: Cambridge University Press, 1992); eadem, Schubert, Müller, and "Die schöne Müllerin" (Cambridge: Cambridge University Press, 1997); and Arnold Feil, Franz Schubert: "Die schöne Müllerin"; "Winterreise," trans. Ann C. Sherwin (Portland, Oreg.: Amadeus, 1988). Two sources that deal with Schubert and poetry in a broader context are: Lawrence Kramer, Music and Poetry: The Nineteenth Century and After (Berkeley: University of California Press, 1984) and Walter Dürr, "Schubert's Songs and Their Poetry: Reflections on Poetic Aspects of Song Composition," in Schubert Studies, ed. Eva Badura-Skoda and Peter Branscombe (Cambridge: Cambridge University Press, 1982). Finally, for those interested in issues related to the analysis of song, I recommend the following two articles by Kofi Agawu: "Theory and Practice in the Analysis of the Nineteenth-Century Lied," Music Analysis 11 (1992): 3-26; and "Perspectives on Schubert's Songs," Music Analysis 16 (1997): 107-22. 
On the surface, the question posed by our protagonist is perfectly straightforward: does the miller's beautiful daughter love him, yes or no? The answer, of course, is not so simple, and in fact the question itself seems somewhat premature considering where this poem falls in the cycle. At this point our shy young hero admires the maid from afar. He has yet to spend time with her, to declare his love for her, and his rival for her affections has yet to appear. He has every reason to be hopeful. Nevertheless, there are subtle clues in Müller's poem to suggest a less-than-positive state of mind. The poem opens from a negative perspective with the young miller telling us whom he will not ask, and then, once he decides on the brook, he says he will ask it if his heart has deceived him. Once he musters the courage to address the brook directly, he describes it first as "silent" and later as "strange," hardly adjectives to bolster confidence. It would seem, then, that the young man has his doubts. As we shall see, there are several features of the music that reinforce this view. That is, it seems quite clear from Schubert's setting that the miller at least suspects that the answer to his question is "no."

The score of "Der Neugierige" is provided at the end of this article. Cursory examination reveals that Schubert has followed the natural division of the five verses into two larger parts, where the first two verses function as an introduction to the last three. This larger division is clearly articulated by changes in metre, tempo, and accompaniment. The first two verses, which set the stage, are set as parallel eight-bar phrases. The tempo is slow and the accompaniment is very simple, perhaps representing the miller's naïveté. The second part of the song is ternary $\left(\mathrm{aba}^{\prime}\right)$, once again paralleling Müller's poem. The vocal lines of verses 3 and 5 are derived from the beginning, but here the accompaniment is flowing, representing the brook to which the young miller is addressing his crucial question.

Gerald Moore has observed that "Der Neugierige" opens with a gesture-the motion to the high $\mathrm{g} \#$ - which "expresses a question mark in musical terms."3 That $g \#$ is left hanging, like a question, by which $I$ mean that it is left unresolved to the expected $f \#$ in the same register. I have marked the $g \#$ as an incomplete neighbour note (IN) and supplied the missing $\mathrm{f} \#$ in parentheses, marked with an asterisk, in figure 1 , a voice-leading sketch of the piano introduction (bars 1-4). In a sense what is truly significant here is not so much the $g \#$, but what is missing, the high $f \sharp$, for, as we shall see, that $f \sharp$ plays a crucial role in this song. ${ }^{4}$ It represents the one word our young miller wants to hear, "yes." There are at least two other features of this introduction worthy of comment. First is the stepwise descent, in what might be described as the tenor voice, from $d \sharp(\hat{3})$ to $b(\hat{1})$ via the lowered third of the scale, $d \xi$. Though introduced here in passing, as part of a secondary diminished seventh chord, this $d \mathfrak{~}$, like the $f \sharp$ just mentioned, also plays an important role in the song. It represents doubt and more specifically the dreaded word "no." Second, I have

3 Gerald Moore, The Schubert Song Cycles (London: Hamish Hamilton, 1975), 19.

4Hereafter, when I want to indicate the octave placement of a notated pitch, I will use the system whereby $c^{1}$ designates middle $C$. Thus the high $f \sharp$ to which I refer is $f \sharp^{2}$. 
marked the inner-voice descent $g \sharp-f \sharp-e-d \sharp(\hat{b}-\hat{5}-\hat{4}-\hat{3})$ with a curly bracket to highlight it because it, or its equivalent in the key of the dominant, reappears later at the close of verse 2 and transition to verse 3.

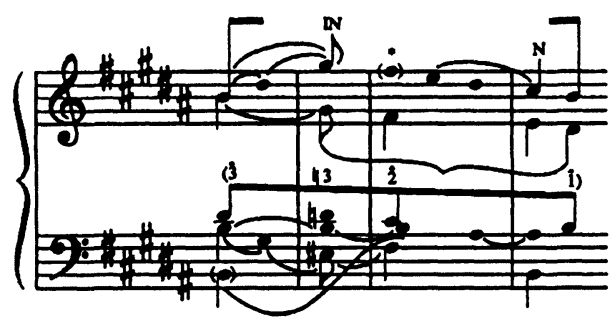

Figure 1: Graph of piano introduction

A graph of Schubert's setting of verse 1 is provided in figure 2. This eight-bar phrase divides naturally into hypermetric groups of two bars (and at a higher level into groups of four), following the pattern established in the piano introduction. The primary melodic motion of the initial four bars is a stepwise ascent to $\hat{3}$ (indicated in the graph by the beam), which is decorated by a secondary motion from above. The diagonal line in the graph indicates the association of the melodic goal of this motion, $d \sharp^{2}$, with the initiating tonic harmony. Interpretation of the voice leading of the second part of the phrase is not so simple. First there is a decorated melodic descent from $\hat{3}$, $d \sharp^{2}-c \sharp^{2}-b \sharp^{1}$, and then in the final two-bar segment $c \sharp^{2}(2)$ is prolonged, initially by the decorative motion from above ${ }^{5}$ and then by a leap to an inner voice. Conceptually and aurally we understand the $c \sharp^{2}$, though literally not present, to be the controlling melodic pitch through the cadence on the innervoice tone $f \sharp$, as indicated in the graph. The overall motion of the phrase following the initial stepwise ascent is $\hat{3}$ to $\hat{2}$ supported by the harmonies I to $\mathrm{V}$. As indicated in the graph, the melodic motion $\mathrm{b} \#-c \sharp$ in the bass in bar 11 , which imitates the same motion in the vocal part just previously, may conceptually be linked to a controlling B in that register from the beginning of the phrase. Though literally not present at that point (and thus its placement in parentheses to indicate its implied status), the low B was sounded just prior to this phrase, at the close of the piano introduction.

5Here and in bar 9 the surface groupings of the decorative motions produce clearly audible thirds, $e^{2}-d \sharp^{2}-c \sharp^{2}$ in bar 9 and $e \sharp^{2}-d \sharp^{2}-c \sharp^{2}$ in bar 11 . While it is important to acknowledge their relationship to other thirds occurring at deeper levels within this phrase/song (a large topic in itself), it is crucial to note that they are not supported by the underlying harmonies. That is, as often happens in tonal music, there is a "conflict" between surface articulation and structural meaning. As shown in figure 2, a structural graph of the voice leading, the $e^{2}$ in bar 9 is neighbouring to the $d \sharp$, and in bar 11 the $e \#$ is an appoggiatura to the $d \sharp$, which is, in turn, neighbouring to the $c \sharp$. Thus these surface articulations, the thirds, do not appear in the graph. 


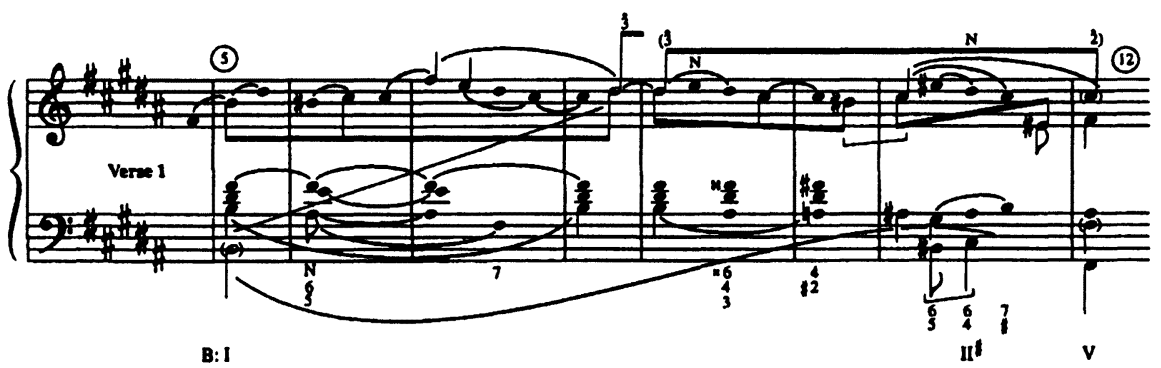

Figure 2: Graph of verse 1, bars 5-12

A more detailed examination of the latter half of this phrase is provided in figure 3. As shown at $(a)$, the bass line may be understood to consist of two strands, an upper line traversing the descending tetrachord $\mathrm{b}-\mathrm{a} \sharp-\mathrm{g} \sharp-\mathrm{f} \#$ and the lower one just mentioned, where the $b \sharp-c \#$ is connected at least conceptually to the earlier sounding B in that register. A detailed examination of the harmonic progression leading to the cadence reveals a rather unusual syntax supporting the text "sie können mir alle nicht sagen," which results, I believe, from the delayed entrance of the low $b \sharp-c \#$ in the bass in order to create the motivic imitation between vocal part and bass, thus uniting more closely the two-bar segments. I have realigned the two strands of the bass line at level $(b)$ of figure 3 for comparison and to show a more normal harmonization of the descending tetrachord of the upper strand. While interesting as a possible explanation of the existing progression, the unfortunate result is elimination of the imitation between vocal line and bass and in its place parallel octaves-a poor substitute for Schubert's sophisticated statement!

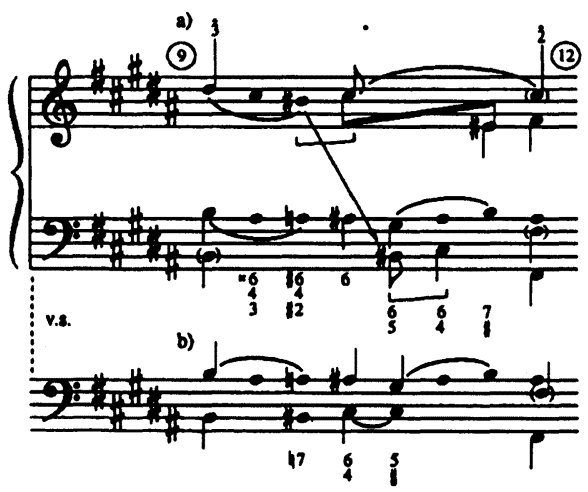

Figure 3: Detailed graph of bars 9-12

As noted above, Schubert's setting of verse 2 parallels that of verse 1 . The first change comes with his setting of the text "mein Bächlein will ich fragen," with the dramatic leaps back and forth between the upper and lower strands of the melodic line, perhaps signaling the miller's agitation. The upper strand 
moves from $d \sharp^{2}$ down to $c \sharp^{2}$ over a weak motion to the dominant harmony, while the lower strand progresses by implication from $e \sharp^{1}$ to $f \sharp^{1}$, as noted in figure 4 . (The motion from $e \sharp^{1}$ to $\sharp^{1}$ is stated explicitly in the accompaniment.) This is followed by an embellished cadence in the key of the dominant. This embellishment is interesting: the underlying pitches of the upper strand-above the prolonged $g \sharp$-are $d \sharp^{2}-c \sharp^{2}-b^{1}-\left(a \sharp^{1}\right)$, that is, scale degrees 6-5-4-(3) in the key of the dominant. This line is highlighted in the graph by the curly bracket to show its relationship to the inner line (the "alto" part) of the piano introduction. (As before the parentheses indicate that a pitch is implied by the voice leading, in this case by resolution of the seventh of the dominant harmony, but not literally present.) This motivic parallel is not particularly noteworthy in itself, but takes on greater significance with its immediate repetition in the following piano interlude, which, as shown, extends the dominant harmony, transforming it from its relatively stable state at the cadence in bar 20 to a seventh chord requiring resolution. Here the connection to the opening is stronger because the repetition occurs in the original key, thus involving the same pitches. As shown by the beams and arrows in figure 4, both strands of the melodic gesture-more specifically the $\mathrm{e}^{2}$ over $\mathrm{c} \sharp^{2}$, that is, the seventh and fifth of the dominant harmony-are left incomplete, their resolutions coming only at the beginning of verse 3 . This is one of the most dramatic moments in the song-the bar of silence (bar 22). Having finally decided to ask the brook if his heart has deceived him, the young man hesitates as if suddenly reluctant to pose his question.

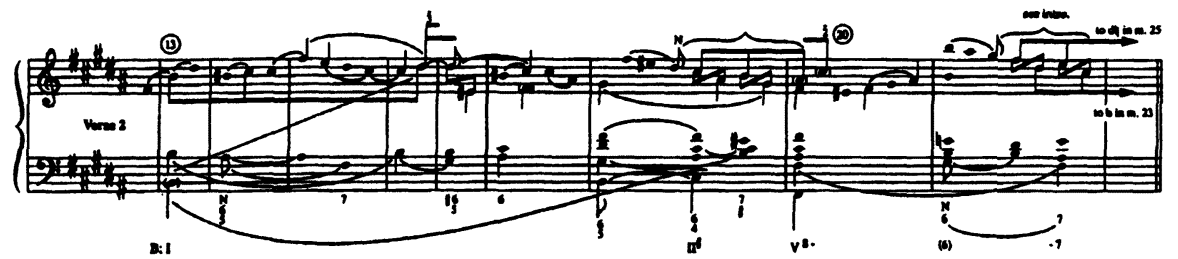

Figure 4: Graph of verse 2, bars 13-22

In our overview of the song it was noted that the second of two parts, where the miller now addresses the brook directly, is differentiated from the first by changes in accompaniment pattern, metre, and tempo. At the same time it is important to note that the underlying structure of the vocal line of verse 3 (and later of verse 5) is derived from that of verses 1 and 2 . There are, however, important differences. First, the stepwise ascent is now to the modally altered third of the scale (dq instead of $d \sharp)$, introducing an ominous quality to the song. As shown in figure 5 , this $d h$ progresses almost immediately to scale degree 2 supported by dominant harmony in the fourth bar of the phrase. In other words, the overall structure of each of the preceding phrases now appears in condensed form. In the consequent part of the phrase the $d \sharp$ is immediately reinstated and, following an initial descent, the melodic line, now embellished, descends to local closure. This embellishment, a setting of the text "ein Wörtchen um und 
um," is extremely important. And just in case the listener might miss the point, Schubert repeats it immediately, extending the phrase by two bars. Here for the first time we have a prominent high $\mathrm{f} \#$, the "missing" pitch in the piano introduction. Furthermore, this high $\mathrm{f} \#$ is the setting for the word "ein." The miller wants to hear one word, and of course that one word is "yes."

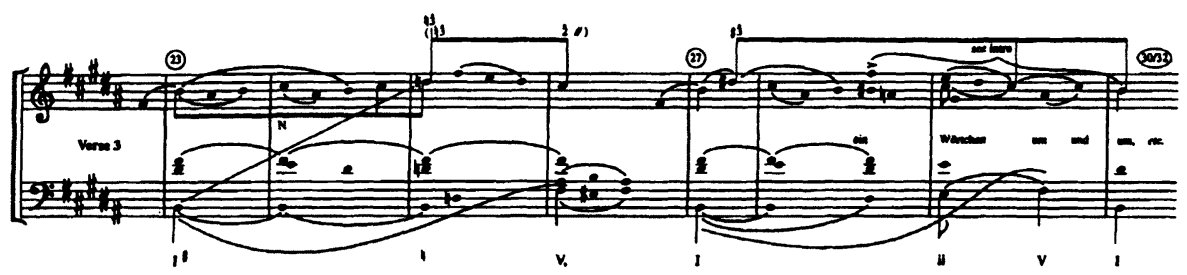

Figure 5: Graph of verse 3, bars 23-32

The first part of verse 4 , which opens with a dominant harmony in six-three position supporting $\hat{2}\left(\mathrm{c} \sharp^{2}\right)$ as the top note, is set in recitative style. The text is: "Ja heisst das eine Wörtchen, das andre heisset nein." Schubert sets the word "ja" with a resounding high $\mathrm{f} \#$. The association with the same pitch near the end of the preceding verse (on the word "ein") could not be made clearer. Indeed the one word he wants to hear is "yes." The other word, "nein," is set as a $d \eta$, which we hear initially as the upper neighbour note of the previously sustained $c \sharp^{2}(\hat{2})$. (As shown in figure 6 , this $d q$ is returned to the $c \sharp$ at the end of the phrase after being "corrected" to the $d \#$; see the piano part, bar 42.) Though here supported by a six-three chord above B, the $d q$ recalls the B-minor harmony of the preceding verse. These two pitches, the high $f \sharp$ and the $d q$, assume very specific associations-in fact, one might say they almost achieve the status of motives-within this song. $F \#$ represents the positive and $d q$ the negative. It is interesting in this regard to note that once the $d q$ is introduced as the setting of "nein," the $f \sharp$, or positive side, is immediately cancelled by the introduction of $f h$ in the following bar (as part of the setting of the next line of the text: "die beiden Wörtchen schliessen die ganze Welt mir ein"). The $\mathrm{f} h$ is introduced as the upper third of the locally prolonged $d q$, from which point the vocal line descends a fifth to a cadence on $G q$. This passage is repeated immediately in slightly embellished form. The additions are two decorative notes in the vocal line, $g q$ as upper appoggiatura of the $f q$ and then $f \#$ as upper appoggiatura of $e$. Though $f \mathfrak{h}$ remains a structural pitch within this local context and $\mathrm{f} \#$ appears only as a decorative one, the reintroduction of the $\mathrm{f} \#$ perhaps might be understood as interjecting a ray of hope within what must be taken as a predominantly negative message. Because of the $f q$, the cadences on $G \xi$ never achieve much of a feeling of stability. Schubert, of course, takes advantage of this. He respells the $f q$ as $e \#$, the augmented sixth above the $G q$, and that harmony is then resolved to the dominant in the original key. In the larger context the $G q$ is heard as the chromatic upper neighbour note of $F \sharp$, the dominant, as indicated in figure 6 , a sketch of this entire passage. 


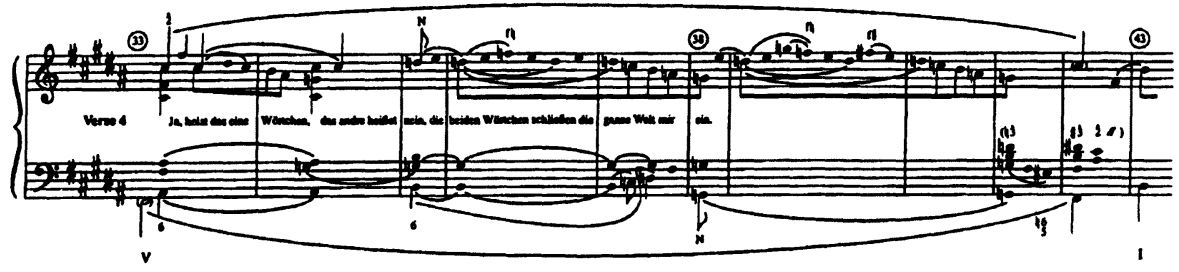

Figure 6: Graph of verse 4, bars 33-42

The musical setting of verse 5 opens parallel to that of verse 3 with a stepwise ascent to the lowered third of the scale $(d q)$, which gives way immediately to $\hat{2}$ supported by the dominant harmony. As before the $d \#(\hat{3})$ is then reinstated (bar 47), from which point our expectation is that the final line of the verse-the crucial question "liebt sie mich?"-will lead to a cadence on the tonic. Instead Schubert avoids closure, this time requiring repetition of the text to bring the song to completion. A detailed sketch of the voice leading of the entire verse is provided in figure 7, and a simplification of the voice leading of this elegant passage (bars 47-52) is provided in figure 8. The descending third $\mathrm{d} \#-\mathrm{c} \#-\mathrm{b}$ connected by a beam, with the first two members supporting decorative third progressions of their own, is a motion from an outer to an inner voice. Schubert avoids closure at this point by the simultaneous reinstatement of the $\mathrm{d} \#$ from above (yet another nested third) and the unexpected harmonic progression to the submediant, thus propelling the motion forwards. (In the larger scheme, this motion to the submediant harmony is shown to be part of the bass progression by descending thirds connecting the tonic and supertonic in first inversion at the cadence.) Examination of the score at this dramatic spot (downbeat of bar 50) reveals that the motion to the $g \#$ minor harmony is given greater emphasis by the chromatic motion $f_{\sharp}-\mathrm{f}^{\mathrm{x}}-\mathrm{g} \sharp$ in the bass, where the accented $\mathrm{f}^{\mathrm{x}}$ supports a secondary dominant. Here I think there are two important, though admittedly speculative, points to be made, one theoretical and the other related to the text. First the theoretical point. The $\mathrm{f}^{\mathrm{x}}$ is enharmonically equivalent to $g \mathfrak{q}$, which earlier in the song, in verse 4 , had achieved momentary stability before falling back to the $\mathrm{f} \#$ as its upper neighbour. Here, however, the $\mathrm{f}^{\mathrm{x}}$ is propelled upward to the $\mathrm{g} \#$, bringing emphasis to the word "mich." Perhaps I am reading too much into this motion, but it suggests to me that the question the young man is really asking, at least in Schubert's setting, is not just "does she love me?", but "does she love me?"

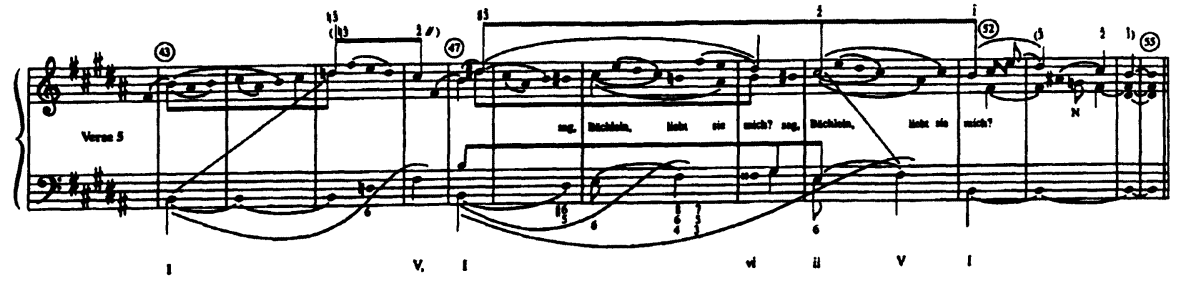

Figure 7: Graph of verse 5 and piano postlude, bars 43-55 


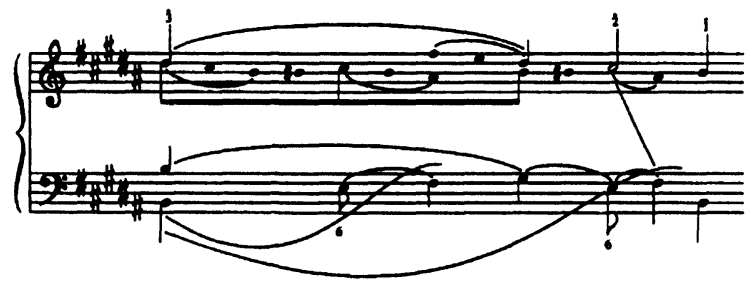

Figure 8: Middleground graph of bars 47-52

The song ends with a four-bar piano postlude over a sustained tonic harmony. The melodic line opens with the familiar ascent to the $d \sharp$, this time accomplished by means of an overlapping e, followed by a descent back to $\hat{1}$. Meanwhile a prominent inner part progresses $f \sharp-g h-f \sharp$, recalling that important motion from earlier in the song.

Schenker's interest in musical structure-in uncovering and describing the basic laws of tonal structure and their representation in the great masterworks-was paralleled by his deep concern for issues directly related to musical performance. In fact, many of his analytic essays, particularly those in Tonwille and Das Meisterwerk in der Musik, ${ }^{6}$ deal extensively with performance matters. As noted at the beginning of this study, it was this aspect of Schenker's work, namely, its practical applications, that interested Greta Kraus the most, and for that reason I would like to conclude my comments about Schubert's "Der Neugierige" with some observations about its performance.

First, as a general observation, it strikes me that this is a very difficult piece to sing well. It must be sung very softly and at a slow tempo, requiring great control. Second, the bar of silence (bar 22) is extremely important, for this is where the young miller hesitates before addressing the brook. Shortening its duration would ruin the effect, whereas stretching it a bit might enhance the drama. Third, there are at least three places where I think ritardandi are appropriate. One is in the brief piano interlude just preceding the bar of silence. The second is in bar 41 , in the piano part, where the $G^{7}$ chord is reinterpreted as an augmented sixth chord leading back to the original key. And the third is in bar 49 at the dramatic moment when the miller asks "liebt sie mich"? I would like the pianist to give a little extra emphasis to the chord over the $f^{x}$ on the downbeat of the following bar to bring our attention to this important moment, and likewise I would like the pianist to bring out the $b \#-c \#$ in the bass in bar 11 so that we can hear the imitation between voice and accompaniment. Finally I would like to say something about the opening gesture in the piano introduction. Though not indicated in the score, I have always thought the first bar should be played with a slight crescendo leading to the chord on the downbeat

6Heinrich Schenker, Der Tonwille, 10 issues (Vienna: A. Gutmann, 1921-24); Das Meisterwerk in der Musik: Drei Jahrbücher (Munich: Drei Masken, 1925, 1926, 1930). 
of bar 2; then a sudden drop in dynamics and perhaps even a change in color for the answering part of the phrase.

Much more could be said about this deceptively simple song-about its structure and about its performance. But I believe this is a good beginning and I hope a fitting tribute to a great Canadian musician, Greta Kraus.

\begin{abstract}
This brief study is a tribute to Greta Kraus who taught for many years in the Faculty of Music, University of Toronto. It is a personal interpretation of a single song, "Der Neugierige" from Franz Schubert's Die schöne Müllerin, following the linear approach developed by Heinrich Schenker, with whom Greta studied many years ago in Vienna. Greta had maintained her interest in Schenker's ideas, particularly their practical application to performance issues, throughout her long and industrious teaching career.
\end{abstract}


Franz Schubert, "Der Neugierige” from Die schöne Müllerin, D. 795
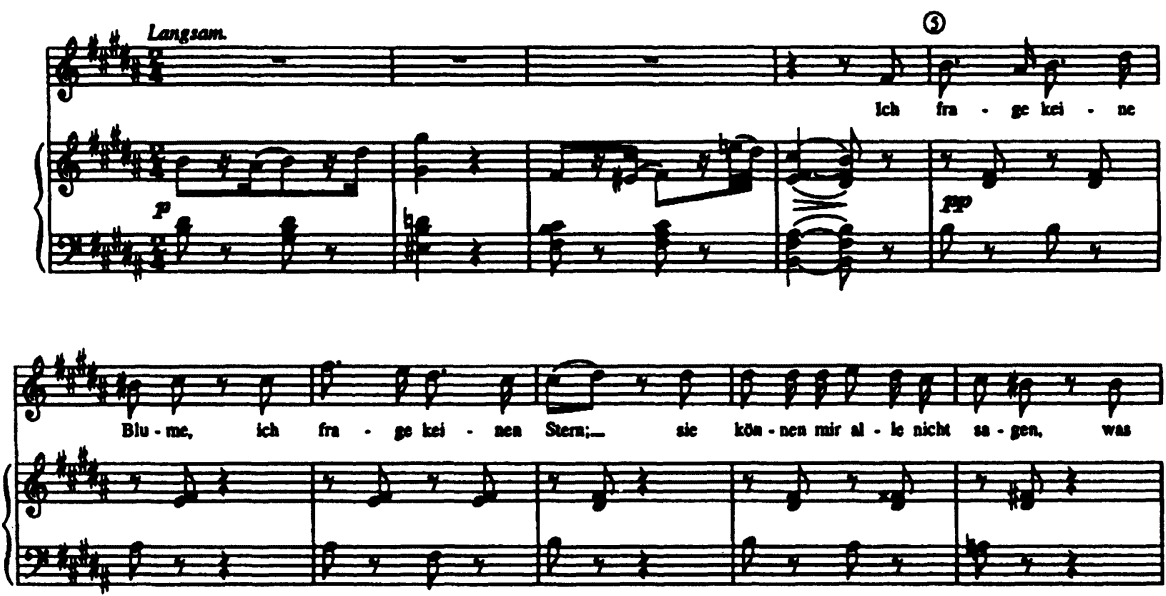

(3)

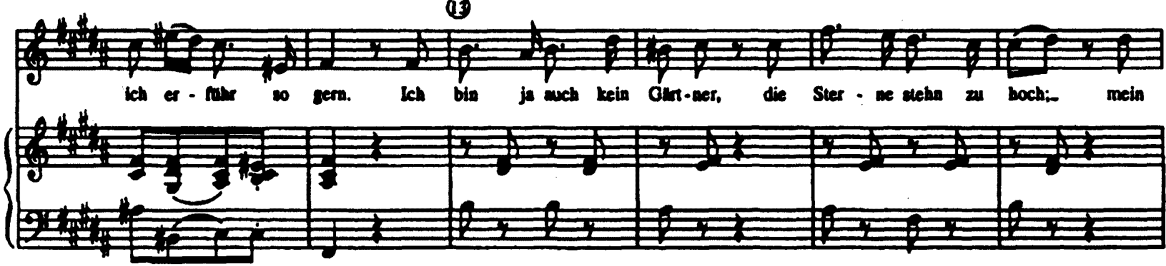

(20)

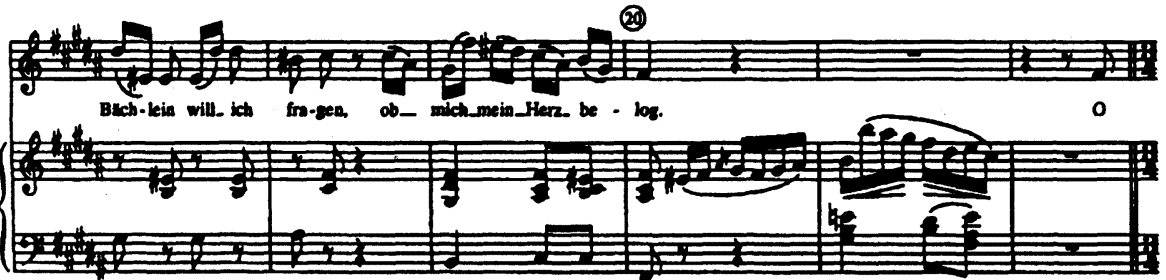

(23)
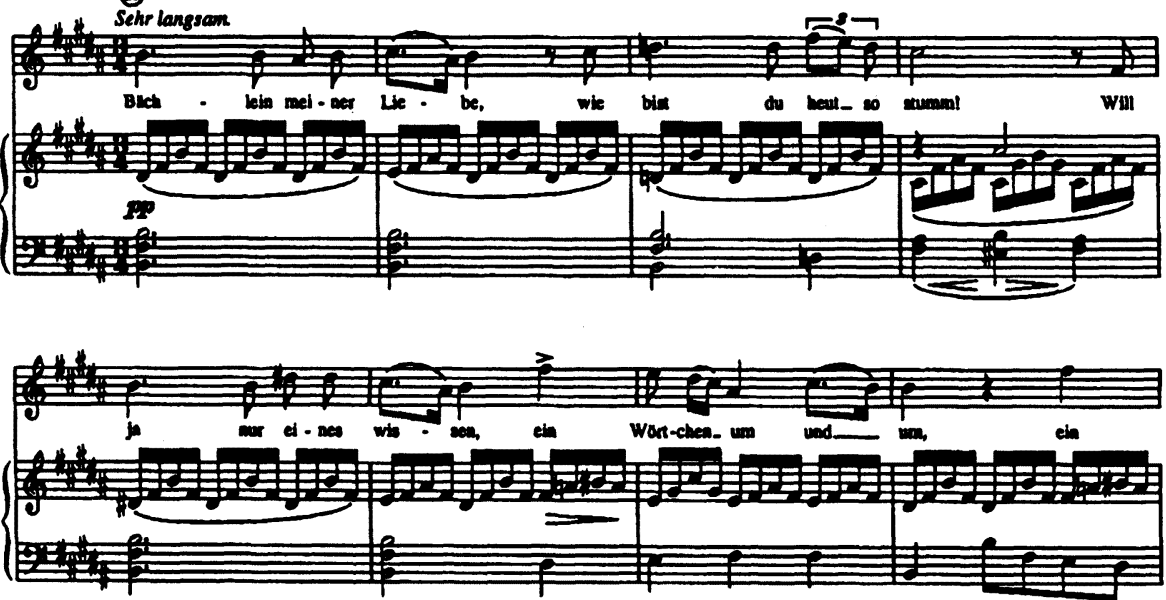
"Der Neugierige"-Continued
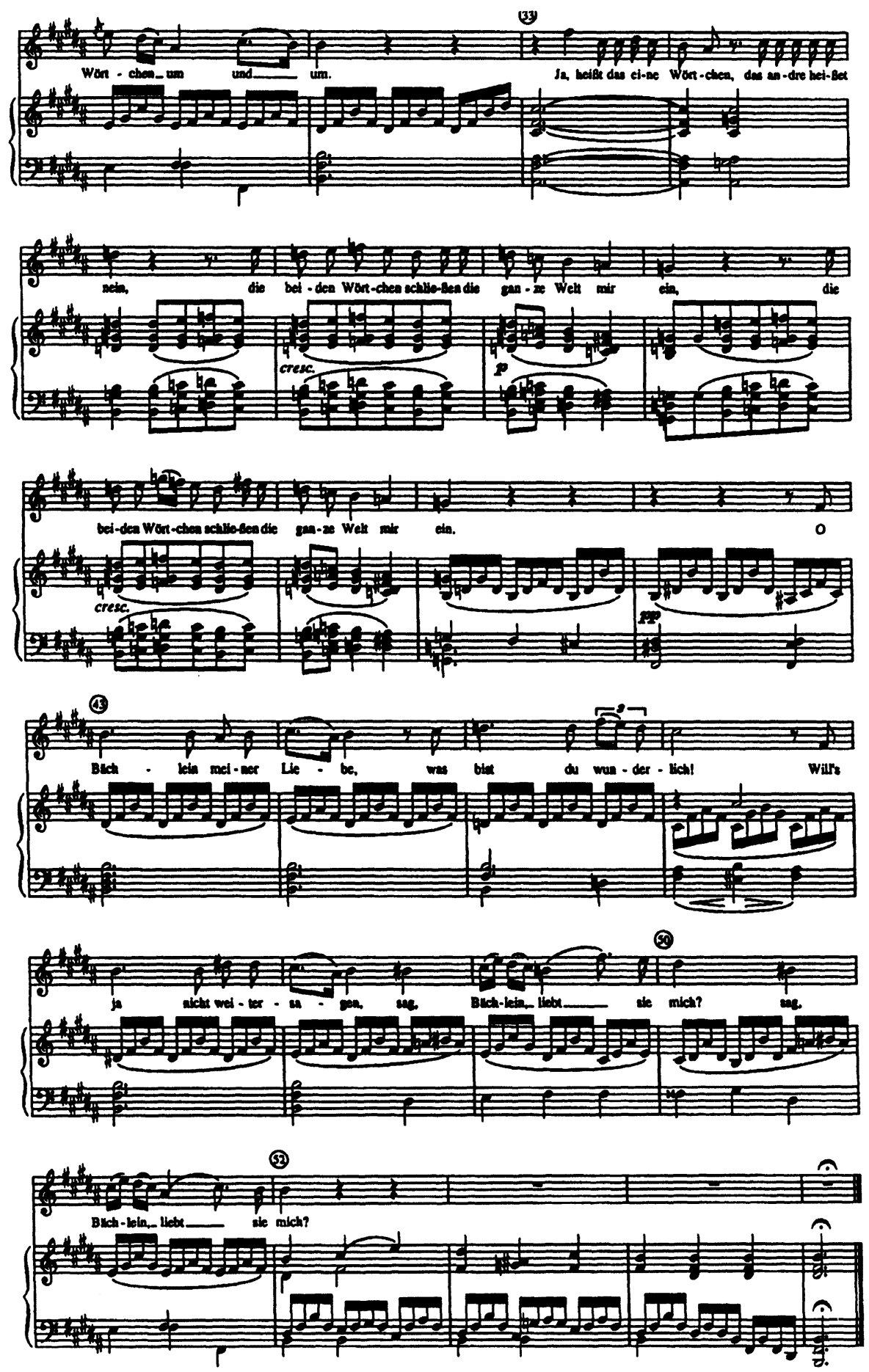